University of Warwick institutional repository: http://go.warwick.ac.uk/wrap This paper is made available online in accordance with publisher policies. Please scroll down to view the document itself. Please refer to the repository record for this item and our policy information available from the repository home page for further information.

To see the final version of this paper please visit the publisher's website. Access to the published version may require a subscription.

Author(s): Taureck, Rita

Article Title: Securitization theory and securitization studies

Year of publication: 2006

Link to published version:

http://dx.doi.org/10.1057/palgrave.jird.1800072

Publisher statement: "This is a post-peer-review, pre-copyedit version of an article published in Journal of International Relations and

Development . The definitive publisher-authenticated version [Taureck, R. (2006). Securitisation Theory and Securitisation Studies. Journal of International Relations and Development, (9) pp. 53-61] is available online at: http://dx.doi.org/10.1057/palgrave.jird.1800072 
Securitization theory and securitization studies

Rita Taureck

Opposed to the recently fashionable 'moral and ethical' criticism levelled against Ole Wæver's securitization theory this article argues that such criticism fundamentally misconceives the analytical goal of securitization theory, which is namely to offer a tool for practical security analysis. In arguing that being political (critical) on the part of the analyst has no bearing on the type of practical security analysis that can be done using securitization theory, this article proposes that the analytical goal of such criticism and that of securitization theory are incommensurable; in the process rendering obsolete this kind of criticism of securitization theory. By way of reconciling securitization theory with its critics, however, this article takes up Wæver's suggestion of wider securitization studies in which moral and ethical criticism, as well as being political, can play a supplementary role in the analysis of securitization theory.

Introduction

In recent years Ole Wæver's securitization theory has been subjected to a seemingly never-ending stream of criticism enthused by moral and ethical motives. Much of this moral/ethical criticism comes from other critical security theories and in general has taken two different forms. The first is concerned with the absence of a normative conceptualization of securitization/desecuritization within the analytical framework of securitization theory. And the second centres on the alleged disregard for the political consequences of Wæver's writing and speaking security himself, in his role as a security analyst (by extension, here Wæver stands for everyone using securitization theory). Such critics come from the entire spectrum of critical security theory. Because of this, and since it is difficult to capture the work of individual theorists within the canonical boxes of but one theory, such critics will be called here 'normative security theorists'. Throughout this article particular emphasis is placed on the work of Claudia Aradau, whose work in the article 'Security and the democratic scene: desecuritization and emancipation' published in the December 2004 edition of this journal, offers one of the model arguments this article criticizes. The present article can thus be partly read as a direct response to Aradau's article.

Although, and as this article will show, much of this criticism has some utility, this utility, however, is not with regard to securitization theory. This is because most of this particular form of criticism is based on a total misunderstanding of the premises of securitization theory. Taking its lead from Wendt (1999) who argues that different research agendas pose different questions, and from Campbell (1998) who argues that the purpose of analysis differs significantly among the different forms of critical security studies, this article will argue that 'securitization theory' aims to answer fundamentally different questions than normative critical security studies, making the goals of the two approaches incommensurable. Based on this premise it will be argued that the moral/ethical criticism levelled at securitization theory is fundamentally flawed. Despite this, some of the criticism is clearly useful and, following Wæver, this article will argue for the accommodation of the normative research question within the realm of wider 'securitization studies'. 
This article begins with a brief overview of securitization theory, focusing on what it is, and on what can be done with it. It will then outline the moral and ethical criticisms levelled against the theory, followed by an explanation of where and how they fall short. Having disarmed the normative critics of securitization theory I will then seek to embrace them and explain why they are nonetheless useful.

I do not wish to claim that securitization theory is a flawless approach that cannot be criticized. Indeed, there is a number of valid criticisms whose enunciators conceive rightly of what securitization theory is and what it can/ cannot do. Given the aim of this article, however, these approaches are irrelevant.

\section{Securitization Theory}

Before I turn to the critics it is necessary to understand securitization theory for what it is and not for what some think it should be. The main argument of securitization theory is that security is a (illocutionary) speech act, that solely by uttering 'security' something is being done. 'It is by labelling something a security issue that it becomes one’ (Wæver 2004: 13). By stating that a particular referent object is threatened in its existence, a securitizing actor claims a right to extraordinary measures to ensure the referent object's survival. The issue is then moved out of the sphere of normal politics into the realm of emergency politics, where it can be dealt with swiftly and without the normal (democratic) rules and regulations of policy-making. For security this means that it no longer has any given (pre-existing) meaning but that it can be anything a securitizing actor says it is. Security is a social and intersubjective construction. That is the meaning of security.

To prevent 'everything' from becoming a security issue, a successful securitization consists of three steps. These are: (1) identification of existential threats; (2) emergency action; and (3) effects on inter-unit relations by breaking free of rules (Buzan et al. 1998: 6). To present an issue as an existential threat is to say that: 'If we do not tackle this problem, everything else will be irrelevant (because we will not be here or will not be free to deal with it in our own way)' (Buzan et al. 1998: 24). This first step towards a successful securitization is called a securitizing move. A securitizing move is in theory an option open to any unit because only once an actor has convinced an audience (inter-unit relations) of its legitimate need to go beyond otherwise binding rules and regulations (emergency mode) can we identify a case of securitization. In practice, securitization is thus far from being open to all units and their respective subjective threats. Rather, it is largely based on power and capability and therewith the means to socially and politically construct a threat. In this way the study of security remains wide, but with restrictions pertaining to 'who' can securitize it is neither unmanageable nor incoherent. This being said it should be noted that Wæver (1998) is extremely critical of framing issues in terms of security. For him: 'security should be seen as a negative, as a failure to deal with issues of normal politics' (Buzan et al. 1998: 29). Because of this, he favours a strategy of desecuritization whereby securitization is reversed and issues are moved out of 'the threat - defence sequence and into the ordinary public sphere' where they can be dealt with in accordance with the rules of the (democratic) political system (ibid.). Although this is clearly a normative statement on the part of Wæver, it is important to notice that it has no bearing on what securitization theory can do. This is so - and this will become much clearer later in this article - because securitization and for that matter desecuritization are political acts and therefore outside of the securitization theorist's personal preference. 
This brief overview shows that securitization theory is not a political statement on the part of the analyst, but that securitization theory is instead a theoretical tool of analysis with which the analyst can trace incidences of securitization and desecuritization. Securitization theory by itself does not enable the analyst to say what security should be/not be. Securitization theory thus seeks to answer the question what does security do? - and little beyond this. In this understanding, securitization theory is nothing but a theoretical tool to facilitate practical security analysis.

\section{Securitization Theory and Its Moral/Ethical Critics}

Considering these relatively clear guidelines on what securitization theory is, what it can do, what it cannot do and what is its purpose, it is quite surprising that much of the criticism voiced against 'securitization theory' is actually a result of something that was never intended to be part of the realm of the theory. Thus, much of this criticism focuses on the absence of any moral/ ethical goals of the theory, and some critics even go as far as to argue that the moral/ethical goals inherent in the theory despite there being none - are false and unethical. How is this possible? The only logical explanation is a misunderstanding of securitization theory by these analysts. Whether or not this misunderstanding is intentional (political) or unintentional is largely irrelevant as the outcome of the serious misrepresentation of securitization theory remains the same.

In order to show what form this misunderstanding takes I will outline some of the most recent criticisms of securitization theory that in my view have led to the most serious misrepresentations of the theory. In what follows, unless otherwise stated securitization theory always refers to political processes of both securitization and desecuritization. Admittedly, much of the criticism in question focuses on the under theorized concept of desecuritization since, like securitization, desecuritization is but a political act, this does not change the core argument of this article. Some of the most fundamental misrepresentations of securitization theory of late can be found in the writings of Claudia Aradau. Drawing on Jef Huysmans, who himself contributed much criticism of this type against securitization theory, Aradau criticizes the moral/ethical dimension in the process of securitization. For her, citing Huysmans,

[securitization] is: a technique of government which retrieves the ordering force of the fear of violent death by a mythical replay of the variations of the Hobbesian state of nature. It manufactures a sudden rupture in the routinized, everyday life by fabricating an existential threat which provokes experiences of the real possibility of violent death (Aradau 2001).

Following this understanding, it becomes clear that securitization here means something very different than it does in Wæver's approach. Thus, no longer is securitization viewed as a theoretical tool that facilities actors' analysis but rather we get to see securitization from the point of view of the securitizing actor, namely as a political method. Here securitization undoubtedly becomes an ethically and morally laden issue that by its very nature is stigmatized as bad. In Aradau's words: ‘[...] both securitising and desecuritising techniques can have disquieting consequences and [...] ethico-political concerns should have prevalence with both securitization and desecuritization or, paraphrasing Michael Dillon, that the story of security should always be an ethical one' (Aradau 2001). Considering this quote it becomes even 
more obvious that we are talking about two different things here, namely 'securitization the theory' and 'securitization the normative practice'. If that is all there is, then there should be no problem. However, this is not the case as all of Aradau's and also Huysmans' writings of this type are direct criticisms of Wæver's securitization theory.

How is this possible? What is such criticism based upon? This criticism is based on the idea that the analyst is never neutral (innocent) in speaking and writing (about) security, but rather co-constitutes political reality. Here, the idea is that the analyst in writing (speaking) about a particular social reality is partly responsible for the co-constitution of this very reality, as by means of his own text this reality is (re)produced. For Wæver - as for all constructivists - such a critique is defeatist as he 'reproduces the security agenda when [he] describes how the process of securitization works' (Huysmans 1995: 69). The only comfort in this dilemma is perhaps that this applies to all constructivist security analysis, as their 'particular understanding of language makes any security utterance potentially securitizing' (Huysmans 1999: 26). Consequently, no such utterance is ever 'innocent or neutral' (ibid.). Huysmans pointedly calls this 'the normative dilemma of speaking and writing security'.

Like a promise is an effect of language, that is, of successfully making the promise, a security problem results from successfully speaking or writing security. It is the utterance of 'security' which politically introduces security questions in a publicly contested policy area. Thus, if successfully performed the speech act makes a security problem (Huysmans 1999: 8).

In other words, in writing or speaking security the analyst him/herself executes a speech act. This speech act is successful if the problem raised becomes recognized as a security problem in the academy and/or in the wider policymaking discourse. For constructivists, including Wæver, the only way is to 'accept the normative dilemma as a dilemma. [The securitization analyst] cannot escape from the fact that its own security writing risks to contribute to the securitization of an area' (Huysmans 1999: 18 and, in recognition of this fact, Wæver 1999: 338).

For Aradau, the existence of the normative dilemma of writing and speaking security means that 'securitization theory' and 'securitization as a normative practice' merge into one - a 'normative securitization theory' which, as I will shortly show, is an oxymoron. For Aradau, the co-constitution of political reality on the part of the analyst means that the analyst has a political responsibility (Aradau 2004: 389). An analyst using securitization theory is therefore political in its very nature. Given the inescapable nature of the dilemma of speaking and writing security this assertion is true, yet now the question is does this matter? From Aradau's position the answer to this question is obviously yes. For her, the whole point of security studies is to problematize existing patterns of security and insecurity. '[S]ecurity [....] needs to be struggled against by appealing to the concept of emancipation, a concept informed by a logic opposed to the logic of security' (Aradau 2004: 401). For Aradau then security is necessarily bad, in fact it is the ultimate disciplining governmental technology. In citing Walker (1997: 78), Aradau reminds us why we have to be political:

[...] it is only in the context of the subject of security that it is 'possible to envisage a critical discourse about security, a discourse which engages with contemporary transformations of political life, with emerging 
accounts of who we might become, and the conditions under which we might become other than we are now without destroying others, ourselves, or the planet on which we all live' (Aradau 2004: 399).

While for normative theorists being political lies at the very heart of their approach to security, in Wæver's securitization theory being political (intended or unintended) is only of secondary importance. This is because being political 'can never replace the political act [that is securitisation/desecuritisation] as such' (Wæver 2000: 252). Securitization/desecuritization is a political choice by a securitizing actor, which the analyst seeks to uncover by means of using securitization theory; hence at this level whether or not the analyst agrees with the securitization/desecuritization in question is irrelevant. Based on this analysis I would like to suggest that in their respective analytical goals normative security theory and securitization theory are incommensurable and, as a result, the ethical/moral criticism directed at securitization theory is misplaced. This incommensurability becomes obvious when comparing which questions the respective research agendas seek to answer, thus securitization theory seeks to answer the positivist question: what does security do? Whereas normative security theorists seek to answer the normative question: what should security do? Misrepresentations and/or faulty criticisms of this kind are not rare in the social sciences as time and again theorists set out to criticize other theorists without considering which kinds of questions the other approach actually sets out to answer. Were, to use David Campbell's phrase, 'the mission statement' (Campbell 1998: 226) of the other theorist to be observed, then much unfruitful criticism could be avoided. It would therefore be useful if every critical engagement would start with thinking about the compatibility between the approaches in question. Alexander Wendt in his seminal work Social Theory of International Relations shows us how this should be done. Throughout the book Wendt keeps on reminding the reader that the difference between research projects - for Wendt rationalism and constructivism - 'is merely that they ask different questions, and different questions need not involve substantive conflict' (Wendt 1999: 33). Such a strategy — as Wendt's book clearly shows does not mean that there can be no criticism, but rather it means that there is a limit to what kind of criticism is fruitful. A criticism that starts from an approach that is incommensurable with the theory to be criticized, aimed at muddling the two together, is neither fruitful nor coherent. Yet this is exactly what Aradau and others have tried to do with securitization theory.

In some ways, however, this is understandable. After all, securitization theory offers one of the most concise and attractive analytical tools in critical security studies today. Moreover, in defence of the critics it could be argued that Wæver, by referring to himself as a 'post-structural realist' with little explanation of what this is supposed to be, as well as his leaving 'desecuritization' under theorized, leaves the door wide open for interpretation. To name but one example, to see what form this interpretation can take it is worthwhile considering Thomas Diez's and Atsuko Higashino's recent proposition that desecuritization entails a strong Habermasian element as it opens up political debate, in that it bears close resemblance to Habermas' 'ideal speech situation' - 'the situation in which argumentative behaviour prevails over strategic behaviour' (Diez and Higashino 2004: 3). In this understanding then, desecuritization itself — as the absence of a world framed in terms of security — becomes an emancipatory ideal. In light of my earlier argument that securitization theory cannot possibly have such normative connotations it appears that all such arguments necessarily become redundant. However, does this mean that they are not useful? 
Does this mean that they contribute nothing to the subject of security? Of course not! To be sure, arguments such as Diez's and Higashino's as well as Huysmans' and Aradau's are far from redundant. This said, two questions arise: what can be done with such criticism? And, what do they offer to the securitization analyst? Perhaps surprisingly a solution to this problem can be found in Wæver's writings where he suggests an outlet for such normative approaches to securitization/desecuritization, in something he labels 'securitization studies' (Wæver 2000: 253). For Wæver 'securitization studies' become the realm wherein the securitization theorist is freed from the ties of securitization theory (i.e. merely observing what is going on), [....] as it is here where the analyst can be political and argue either for or against an incidence of securitization. Informed by securitization studies, Wæver hopes that 'political action [....] might be able to contribute to minimizing or curtailing dynamics of mutual provocation and securitization' (ibid.). Thus, it is here where the securitization analyst can support an emancipatory ideal. It is here where Wæver himself finds an outlet for his own preference for desecuritization.

Having said this, it is important to note that for Wæver, policy-makers cannot simply be informed/advised on the basis of an ill-defined emancipatory ideal (such as the post-structuralist security theorist's desire to radically open up debate and struggle against security) because all political situations are unique and therefore no single solution can ever suit all problems. Accordingly, it must be the task of the security analyst to act virtuously in both his analysis and advice.

As a security/securitisation analyst, this means accepting the task of trying to manage and avoid spirals and accelerating security concerns, to try and assist in shaping the continent [Europe] in a way that creates the least insecurity and violence - even if this occasionally means invoking/ producing 'structures' or even using the dubious instrument of securitisation (Wæver 2000: 285).

From a theoretical point of view then, securitization studies serve as an outlet for all those moral and ethical criticisms that are of no relevance to securitization theory. This said, however, it is crucial to notice that from the point of view of a securitization theorist the moral/ethical advice offered within the wider realm of securitization studies is subordinate to the findings of securitization theory as - and I reiterate - being political can never replace the political act that is securitization/desecuritization, it can only supplement it.

\section{Conclusion}

This article has aimed to draw attention to the fact that much of the recently voiced morally and ethically motivated criticism against securitization theory completely misperceives the analytical goal inherent in the theory. This article has dared to make the unfashionable argument of incommensurability, in that it argues that the aims of 'securitization theory' and what has been called here 'normative security theory' are beyond comparability. Initially much criticism was voiced against the work of Claudia Aradau, whose work has merely been singled out as a prime example of such misconceived criticism. Despite the argument of incommensurability and the rejection of normative criticism's utility for securitization theory, it has been argued that such criticism becomes relevant within the framework of wider 'securitization studies' 
where being political plays a supplementary role to the groundwork provided by securitization theory.

\section{References}

Aradau, Claudia (2001) 'Beyond Good and Evil: Ethics and Securitization/Desecuritization

Techniques', Rubikon: International Forum of Electronic Publications (December): available at

http://venus.ci.uw.edu.pl/Brubikon/forum/claudia2.htm (15 December, 2005).

Aradau, Claudia (2004) 'Security and the Democratic Scene: Desecuritization and Emancipation',

Journal of International Relations and Development 7(4): 388-413.

Buzan, Barry, Ole Wæver and Jaap de Wilde (1998) Security: A New Framework for Analysis,

Boulder, CO: Lynne Rienner.

Campbell, David (1998) Writing Security (Revised edition). Minneapolis, MN: University of

Minnesota Press.

Diez, Thomas and Atsuko Higashino (2004) '(De)Securitisation, Politicisation and European

Union Enlargement', Coventry: University of Warwick, paper presented at the BISA 29th

Annual Conference, 20-22 December.

Huysmans, Jef (1995) 'Migrants as a Security Problem: Dangers of "'Securitizing”, Societal Issues',

in Robert Miles and Dietrich Thraenhart, eds, Migration and European Integration:

The

Dynamics of Inclusion and Exclusion, 53-72, London: Pinter.

Huysmans, Jef (1999) 'Language and the Mobilization of Security Expectations: The Normative

Dilemma of Speakingand WritingSecurity', Paper presented at the ECPR Joint Sessions,

Mannheim, 26-31 March.

Walker, Rob B.J. (1997) 'The Subject of Security', in Keith Krause and Michael Williams, eds,

Critical Security Studies: Concepts and Cases, 61-82, London: UCL Press.

Wæver, Ole (1998) 'Security, Insecurity and Asecurity in the West-European NonWar

Community', in Emmanuel Adler and Michael Barnett, eds, Security Communities, 69-118,

Cambridge: Cambridge University Press.

Wæver, Ole (1999) 'SecuritizingSectors? Reply to Eriksson', Cooperation and Conflict 34(3): 334-

40.

Wæver, Ole (2000) 'The EU as a Security Actor: Reflections from a Pessimistic Constructivist on

Post Sovereign Security Orders', in Morten Kelstrup and Michael C. Williams, eds, International 
Relations Theory and the Politics of European Integration, 250-94, London: Routledge.

Wæver, Ole (2004) 'Aberystwyth, Paris, Copenhagen: New Schools in Security Theory and the

Origins between Core and Periphery', Montreal: ISA Conference, March.

Wendt, Alexander (1999) Social Theory of International Relations, Cambridge: Cambridge

University Press. 